\title{
Secondary School Principals and Their Efficient Management of School Records in Delta State, Nigeria
}

\author{
Osakwe, Regina N. (Ph.D.) \\ Department Of Educational Administration And Policy Studies, Delta State University, Abraka
}

\begin{abstract}
This study examined the efficient management of school records by secondary school principals in Delta state, Nigeria. As a descriptive survey, the study population comprised of all the 602 public secondary school principals. The 602 principals were used as sample. A structured questionnaire was used to gather data which was subsequently analyzed using the mean scores and z-test statistics to answer the three research questions and to test the three hypotheses, respectively. The findings revealed that secondary school principals differ in their efficient management of school records in terms of gender, experience and school location. Based on these findings, it was recommended that government should provide adequate funds and facilities for the effective management of school records and there should be adequate training and retraining of principals through in-service programmes, conferences, seminars and workshops. Also effective supervision of school principals is necessary irrespective of gender, experience and school location.
\end{abstract}

Keywords: Management, Principals, School records, Secondary schools, Delta state, Nigeria

\section{Introduction}

Records are defined as all those documents which facilitate the business carried out by the school and which are thereafter retained (for a set period) to provide evidence of its transactions. These records may be created, received or maintained in hard copy or electronically. School records are official documents, books and files containing essential and crucial information of actions and events which are kept and preserved in the school office for utilization and retrieval of information when needed. Such records are kept by principals, teachers, counselors or administrative staff. The purpose of record keeping and management is to ensure that accurate and proper records of students achievement and growth, information on school activities and matters that will promote efficiency and effectiveness of the school system are kept. According to Durosaro (2002), records are important tools for effective planning and administration of a school. School records occupy strategic position in the effective and efficient organization and administration of the school, for the documentation, the planning and the implementation of appropriate course of actions thereby allowing proper monitoring of activities/tasks. Records are important because they serve as major information tool that sustains the school and aids in achieving educational goals and objectives. Records restore teaching competence and maintain the trend in the history of teaching and learning processes.

Egwunyenga (2009) suggested that not all information can be considered as records until they satisfy such characteristics as genuinety and authenticity. That is the information that records give must be true, correct and original. The records must be comprehensive, available, accessible and secured. School records are grouped into statutory and non-statutory. Statutory records include admission/withdrawal register, attendance register, scheme of work, time-table, logbook, visitors book, time/movement books, school diary, lesson plan/note for teachers, examination record book, etc. Non-statutory records are cash book, stock book, punishment book, school calendar, inventory book, staff minutes book, school magazine, inspection/supervision report file, confidential report forms and requisition book.

Thus the school recognizes that the efficient management of its records is necessary to comply with its legal and regulatory activities and to contribute to the effective overall management of the institution. The principal who is responsible for records management in the school will give guidance for good records management practice and will promote compliance with the school policy so that information will be retrieved easily, appropriately and timely. Therefore record management is the application of systematic and scientific control of recorded information that is required for the operation of the school. Such control is exercised over the distribution, utilization, retention, storage, retrieval, protection, preservation and final disposition of all types of records within the school. The aim of record management is to achieve the best retrieval and exploitation of school records in the school system and also to improve the efficiency of record making and keeping processes.

Record management helps to control the quality and quantity of information that is created in a manner that effectively serves the need of the school (Akube, 1991; Fasasi, 2004). School record management according to Fasasi (2004) is meant to enhance the performance of secondary school administrators. Adequate records management programme co-ordinates and protects an institutions records, sharpens the effectiveness of records as a management memory which controls the times, equipment and space allocated to records and helps to 
simplify intra-organizational and communication problems. The management of records in the secondary schools like in any other organization is a cyclic process involving the principals, teachers, students, messengers and cleaners. The bulk of records are handled by principals that are kept manually, thus the processing, retrieval and utilization of records are not easy.

Iwhiwhu (2005) stresses the insufficient quality and quantity of manpower in records management in the school system. He emphasized that manpower is employed without prejudice to qualitative records management. Though this business of record keeping and effective management in the secondary school system has not attained good success due to insufficient provision of facilities, fund and management components. However, adequate security, storage facilities and funds are generally recommended for good record keeping and management (Tower Software, 2004).

Iyede (2001) viewed human resource management as the harnessing of the totality of the peoples skills, energies, talents, latent capacities, social characteristics like beliefs to achieve educational objectives and simultaneously making people to be part and parcel of the school. This shows that manpower energies, skills and latent capabilities are harnessed to meet organizational goals. Also an enabling and conducive environment and enough motivation are needed for the workers in the school to put in their best.

Asogwa (2004) asserts that records and data generated in the course of execution of legitimate function of an organization or school should be kept and managed properly. However, despite the overwhelming importance of school records, it has been observed that they are poorly kept and managed. School records whether statutory or non-statutory, physical or electronic should be properly kept and managed for utilization and future retrieval. The term management has been defined as the process of utilizing material and human resources to accomplish designated objectives which involve the organization, direction, supervision, coordination and evaluation to achieve organizational objectives. Aghenta (2001) defined management as a process involving organizing, planning, leading, measuring and controlling as well as undertaking of risk and handling of uncertainty, planning and innovation, coordination and routine supervision. It is also a process designed to ensure the co-operation, participation, intervention and involvement of personnel in the effective achievement of a given objective (Fabunmi, 2000).

The effective management of school records by principals depends on certain management procedures and functions such as effective supervision, creation of records, effective leadership, monitoring, provision and training of adequate personnel, records storage and retrieval, discipline and effective communication, delegation of duty, developing record keeping skills and motivation (Ajayi, 2001; Babalola, 2002; Egwunyenga, 2009; Adeyemi, 2008). Information and data generated from an effective and efficient records management programme aids the school to plan and make useful decisions, preserve facts and figures for future reference, thereby enhancing the efficiency and effectiveness of the organization and administration of the school. The adequate provision of quality manpower, funds and equipment would ensure optimum management of school records however, inadequate or non-availability of these resources would bring about problems and challenges in the efficient and effective management of records. Since all schools are expected to keep records for effective and efficient achievement of educational goals and objectives, it was pertinent to examine whether the records are managed properly or not in Delta State Secondary Schools, Nigeria.

\section{Statement of Problem}

Despite the importance of school records in the achievement of educational objectives, these records do not seem to be adequately managed by principals. From observation, it becomes obvious that accurate, reliable and trustworthy records that fulfill evidential requirements are being created but not properly managed. Egwunyenga (2009) emphasized that record management practice in Nigeria has a number of problems which may include insufficient skilled and experienced record management personnel and possibly low priority of record management in the scheme of things. Thus, management of school records becomes an issue of great concern to education stakeholders, parents, students, individuals, government and non-governmental organization.

Many principals complain of the shortage of trained personnel, funds and material resources. These could possibly have serious connotations on management of school records by principals in Delta State Secondary Schools. Thus, the problem of this study examines how the principals of secondary schools differ in their management of school records with regards to gender, experience and location.

\section{Research Questions}

In view of the problem of the study presented in the preceding section, this study seeks answers to the following questions:

- Do male and female secondary principals differ in their efficient management of school records?

- Do experienced and less experienced secondary school principals differ in their efficient management of school records? 
- Do urban and rural secondary school principals differ in their efficient management of school records?

\section{Hypothesis}

The hypotheses were formulated to guide the study:

- There is no significant difference in the efficient management of school records between male and female principals of secondary schools in the Delta state.

- There is no significant difference in the efficient management of school records between experienced and less experienced secondary school principals.

- There is no significant difference in the efficient management of school records between urban and rural secondary school principals in the Delta state.

\section{Purpose of the Study}

The purpose of this study is to investigate the principals' efficient management of school records in secondary schools in Delta state, Nigeria. Specifically, the study will examine the following:

- If there is any significant difference in the efficient management of school records between male and female secondary schools.

- Whether experienced and less experienced secondary school principals differ in the efficient management of school records.

- How urban and rural secondary schools principals differ in the efficient management of school records.

\section{Materials and Methods}

Design: The survey design was utilized in this study. This study was descriptive in nature to identify and make selection of variables which are considered relevant to this investigation.

Population and Sample: The study population comprised all the (602) public secondary schools made up (602) principals in Delta state, Nigeria. All the schools were selected as well as their principals. The entire population was therefore used and no sampling was carried out.

Research Instrument: The instrument used to collect data for the study was a self-developed questionnaire. The instrument was validated by experts in educational administration, and measurement and evaluation who matched each item with the hypotheses to determine whether the instrument actually measured what it supposed to measure. Thus, the face and content validity was established. The reliability of the instrument was determined through the test re-test technique. The scores obtained were correlated using the Pearson product Moment correlation analysis. A correlation coefficient of $r=0.82$ was obtained indicating that the instrument was reliable for the study. The collected data were analyzed using z-test statistical tool. The hypotheses were tested for significance of 0.05 alpha level.

\section{Results}

Research Question 1: Do male and female secondary school principals differ in the efficient management of school records?

Hypothesis One $\left(\mathbf{H O}_{1}\right)$ : There is no significant difference in the efficient management of school records between male and female principals in secondary schools in the state.

Table 1: Z-test analysis showing the difference in the efficient management of school records between male and

\begin{tabular}{l|cccccccc}
\multicolumn{10}{c}{ female secondary school principals. } \\
\hline Variables & N & $\bar{X}$ & SD & DF & Z-cal. & Z-crit. & Decision & Level of Sig. \\
& & & & & & & & \\
\hline Male principals & 202 & 18.80 & 1.41 & 600 & 4.26 & 1.96 & Significant & 0.05 \\
Female principals & 400 & 19.41 & 1.87 & - & - & - & - & - \\
\hline
\end{tabular}

In table 1, the mean value of male principals with regards to management of school records was 18.80 with standard deviation of 1.41 for a sample 202. This was less than that of female which was 19.41 mean value with SD of 1.87 for a sample of 400 .

The calculated z-value was 4.26 with degree of freedom (df) 600 at 0.05 level of significance. The obtained $z$-value was greater than the table value of 1.96, therefore the null hypothesis was rejected. This showed that there was a significant difference in the efficient management of school records between male and female secondary school principals. 
Research Question 2: Do experienced and less experienced secondary school principals differ in the efficient management of school records?

Hypothesis Two $\left(\mathrm{HO}_{2}\right)$ : There is no significant difference in the efficient management of school records between experienced and inexperienced secondary schools principals in Delta state.

Table 2: Z-test analysis showing the difference in the efficient management of school records between experienced and less experienced secondary school principals in the state.

\begin{tabular}{l|cccccccc}
\hline Variables & N & $\bar{X}$ & SD & DF & Z-cal. & Z-crit. & Decision & $\begin{array}{c}\text { Level of } \\
\text { Sig. }\end{array}$ \\
\hline Experienced principals & 402 & 17.52 & 2.25 & 600 & 2.42 & 1.96 & Significant & 0.05 \\
Less experience principals & 200 & 16.91 & 2.93 & - & - & - & - & - \\
\hline
\end{tabular}

The mean value of experienced principals as shown in table 2 was 17.52 with SD of 2.25 for a sample of 402 was greater than that of the less experienced principals which was 16.91 with SD 2.83 for a sample of 200. The difference in the mean value revealed that experienced principals are more competent in the efficient management of school records than their counterparts. The calculated z-value of 2.42 was greater than the critical value of 1.96 at 0.05 level of significance. Therefore, the null hypothesis was rejected.

This showed that there was a significant difference in the efficient management of school records between experience and less experienced principals.

Research Question 3: Do urban and rural secondary school principals differ in the efficient management of school records?

Hypothesis Three $\left(\mathbf{H O}_{3}\right)$ : This hypothesis states that there is no significant difference in the efficient management of school records between urban and rural secondary schools principals.

Table 3: Z-test analysis showing the difference in the efficient management of school records between urban and rural secondary school principals.

\begin{tabular}{l|cccccccc}
\hline Variables & N & $\bar{X}$ & SD & DF & Z-cal. & Z-crit. & Decision & $\begin{array}{c}\text { Level of } \\
\text { Sig. }\end{array}$ \\
\hline Urban principals & 420 & 22.71 & 4.68 & 600 & 5.47 & 1.96 & Significant & 0.05 \\
Rural principals & 182 & 17.93 & 3.92 & - & - & - & - & - \\
\hline
\end{tabular}

Table 3 shows that the mean value for urban principals is 22.71 with SD 4.68 and that of rural principals were 17.93 with SD of 3.92. The calculated z-value 5.47 and the critical z-value was 1.96. Since the $\mathrm{z}$-calculated was greater than the z-critical, the null hypothesis is therefore rejected. The result showed a significant difference in the efficient management of school records between urban and rural secondary school principals. This implies that there is no similarity in the efficient management of school records by urban and rural principals.

\section{Discussion}

From the analysis of data, it was found that there was a significant difference in the efficient management of school records between male and female principals in secondary schools in the state. It was revealed that male and female secondary school principals differ in the efficient management of school records. Female principals have a mean score of 19.41 which is higher than the male principals showing that female principals have more skills and latent capabilities in the efficient management of school records. This finding agrees with Iyede (2001) who viewed human resources management as the harnessing of the totality of the people's skills, energies, talents and latent capabilities to achieve educational objectives which management of school records is part and parcel of. The study also revealed that there was a significant difference between experienced and less experienced principals in the efficient management of school records in Delta state secondary schools.

The study revealed a higher mean score of 17.52 by experienced secondary school principals. This implies that experienced principals are more efficient in the management of school records due to long term experience gained from management procedures and functions like supervision, leading, controlling, planning, organizing and administering the activities of the school. This finding supports that of Ajayi (2001) who in their various studies stipulated that efficient management of school records depends on certain management procedures and functions.

The study came up with another finding that a significant difference exists between urban and rural principals in the efficient management of school records in secondary schools of Delta state. Urban secondary school principals indicate a higher mean score of 22.71 which showed that management of school records is 
more effective in urban schools than rural schools. This could be that urban principals are exposed to modern technological facilities, adequate funds and resources for storage, retrieval and usage of school records. It may also be due to the fact that school inspectors have easy access to supervise the activities of urban secondary schools than rural secondary schools. This finding is in consonance with the study of Tower Software (2004) that funds, electronic records management system and effective supervision are essential components of efficient management of school records.

\section{Conclusion}

This study examined secondary school principals and their efficient management of school records in Delta State. Based on the findings of this study, the researcher concludes that there exist differences in the efficient management of school records by secondary school principals with regards to gender, experience and location in Delta state, Nigeria. Thus female and experienced principals have more skills, and more efficient in the management of school records. Also urban principals are more efficient in the management of school records due to exposure to modern technological facilities and resources for keeping and storing records.

\section{Recommendations}

Considering the findings of this study, it is hereby recommended that:

- Government should provide adequate funds and facilities for the efficient management of school records.

- There should be adequate training and retraining of school principals on efficient management of school records through seminars, workshops and conferences irrespective of gender, experience and school location.

- $\quad$ There should be adequate supervision by the state education board to ascertain accurate record keeping and efficient management of school records by principals irrespective of school location.

- The essential records needed for the administration and organization of the school should be provided and properly kept for the achievement of educational objectives.

\section{References}

[1]. Adeyemi, T.O. (2008). The influence of management strategies on the effective keeping of school records in secondary schools in Ekiti State, Nigeria. The Social Science, 3:28-36.

[2]. Aghenta, J.A. (2001). Educational planning: A turning point in education and development in Nigeria. Inaugural Lecturer Series 58, University of Benin, Benin-City, Nigeria.

[3]. Ajayi, A.E. (2001). Human resources management in the civil service. Presented at the Senior Staff Seminar, Ministry of Education, Ado Ekiti.

[4]. Akube, A.U. (1991). Classroom organization and management: A 5-point strategy. Wisdom Publishers Ltd., Ibadan.

[5]. Asogwa, G.E. (2004). Library records and maintenance. Journal of Library Information Science, 2:88-98.

[6]. Babalola, J.B. (2002). Benefit analysis and project management. Centre for external studies, University of Ibadan, Ibadan, pp. 6873.

[7]. Durosaro, D.O. (2002). Management of school records. In Durosaro, F.O. and S. Ogunsaju (Eds.): The craft of educational management. Indemac, Ilorin, pp. 138-152.

[8]. Egwunyenga, E.J. (2005). Essentials of school administration. Justice Jeco Publishers, Benin-City, Nigeria.

[9]. Egwunyenga, E.J. (2009). Record keeping in universities: Associated problems and management options in South West GeoPolitical Zone of Nigeria. International Journal of Education Science, 1:109-113.

[10]. Fabunmi, F.A. (2000). Application of management principals to the administration of primary school libraries in Nigeria. Journal of Educational Management, 8:234-244.

[11]. Fasasi, Y.A. (2004). School record keeping: A strategy for management of Nigerian secondary education institutions. Ilorin Journal of Education, 23:73-78.

[12]. Iwhiwhu, B.E. (2005). Management of records in Nigeria universities: Problems and prospects. Journal of Electronic Library, 23:345-355.

[13]. Iyede, R.O. (2001). Managing human resources. In Peretomode, V.F. (Ed.): Introduction to educational administration, planning and supervision. Joja Educational Research and Publishers Ltd., Lagos, Nigeria.

[14]. Tower Software (2004). Best practice in corporate record keeping and archiving. Head Office Camberra ACT. http://www.versapac.com.my/papers/corporate_best_practices.pdf. 